\title{
GLOBAL CITIZENSHIP EDUCATION AND THE IDEA OF DIVERSE EPISTEMOLOGIES
}

\begin{abstract}
Three broad kinds of orientation can be identified with regard to (global) citizenship education (GCE): cosmopolitanism, localism, and relationalism. They differ in their respective approaches not only to cultural transmission and instruction but also to knowledge and knowledge production. My aim in this paper is to interrogate the notion of local or indigenous knowledge in GCE research and to investigate whether the postcolonial idea of diverse epistemologies does not employ a mistaken sense of 'epistemology'. I argue that there are good reasons for an unequivocal and universally applicable understanding of knowledge and epistemology in (global) citizenship education and GCE research and for being able to distinguish between knowledge and non-knowledge. Geographic, ethnic, racial and gender-based origin and affiliation do not constitute relevant criteria for any such demarcation. Instances in which they are cited as criteria raise questions not of epistemological relevance but rather of social justice.
\end{abstract}

Keywords: education; citizenship; epistemology; diversity.

\section{Introduction}

Several claims have been made in recent years regarding the relevance of different conceptions of knowledge and knowledge production for (global) citizenship education (GCE) in the postcolonial era. One of the most remarkable developments in GCE and GCE research over the past quarter-century has been the proliferation of 'epistemologies' (see Pallas, 2001, p. 6) - beliefs about what counts as knowledge in the field of citizenship education, what counts as evidence or justification for a claim, and what constitutes warrant for that evidence. If (prospective) citizens cannot understand and interact with one another, both within and across communities,

* $\mathrm{PhD}$ Kai Horsthemke, associate professor at the Catholic University Eichstätt-Ingolstadt in Germany, visiting professor in the School of Education at the University of the Witwatersrand, South Africa, and a fellow at the Oxford Centre for Animal Ethics, UK; e-mail: Kai.Horsthemke@ku.de. 
the educational (not to mention the political) enterprise is doomed to failure. Thus, to prevent "a recurring pattern of epistemological single-mindedness" (p. 7), global citizens will need to engage with diverse epistemological perspectives to the point that members of different communities and cultures can understand one another, despite or perhaps because of their differences. Preparing future citizens for such epistemological diversity is arguably one of the most important things that faculties of research universities can do. Insofar as all phases of the education process are supported by epistemologies, engaging with epistemology is integral to learning the craft of (global) citizenship. Moreover, epistemologies shape citizens' abilities to understand and respect the status, beliefs and values of others. "Such an appreciation", as Aaron Pallas (2001, p. 6) points out, "is a prerequisite for the scholarly conversations that signify a field's collective learning".

My aim in this paper is to interrogate assertions regarding the notion of local or indigenous knowledge in (G)CE research (Swanson, 2015, p. 32) and to investigate whether the postcolonial idea of diverse epistemologies does not employ a mistaken sense of 'epistemology'. I argue that there are good reasons for an unequivocal and universally applicable understanding of knowledge and epistemology in (global) citizenship education and (G)CE research - and for being able to distinguish between knowledge and non-knowledge. Geographic, ethnic, racial and genderbased origin and affiliation do not constitute relevant criteria for any such demarcation. Instances in which they are cited as criteria raise questions not of epistemological relevance but rather of social justice.

\section{Epistemological foundation of (global) citizenship education: cosmopolitanism, localism, and relationalism}

Three broad kinds of orientation can be identified with regard to (global) citizenship education, or (G)CE: cosmopolitanism, localism, and relationalism. They differ in their respective approaches not only to cultural transmission and instruction but also to knowledge and knowledge production.

Cosmopolitanism is characterised by acceptance of and neutrality towards all cultures just insofar as these are not intolerant, disrespectful and unjust (see Nussbaum, 2002; Papastephanou, 2005). Cosmopolitan education would include exposure to a wide array of cultural goods and life plans, as well as the greatest possible exposure to conceptions of the good life. This also comprises access to different epistemological orientations: epistemological foundationalism like naturalism, empiricism and rationalism, and anti-foundationalism like pragmatism, interpretivism and standpoint theory, exposure to which would facilitate both interpersonal understanding and personal decisions regarding a "good life". The

1 Pallas is concerned with educational researchers at doctoral level, rather than present and future citizens, but his ideas are generative also in the present context. 
global citizen in this sense is an informed, critical and effective thinker, guided by impartiality, reason, and universal values.

By contrast, localism focuses solely on imparting local culture. Indigenous education is meant to teach partiality and loyalty towards local values, worldviews and culturally relevant and situated ways of knowing. Maintenance and preservation of the cultural heritage and status quo trump all experimentation with what is foreign or 'other'. The views and opinions of community elders and tribal 'sages' are of primary epistemic relevance. Localism is critical not only of the idea of a global citizenship agenda but also of global or universal knowledge. All knowledge is relative, "local" (Higgs, 2018, p. 213; Swanson, 2015, p. 32), necessarily 'situated' (Abdi, 2015, p. 23), just as evaluation and values, too, are relative or culturally specific. There is, therefore, a wide range of culture-, ethnicity-, race- and gender-based epistemologies, none of which are objectively superior or inferior to any other. References to diverse epistemologies are connected with reclaiming epistemic goods, repossession of historically suppressed or marginalised orientations and views. Just as all knowledge is local and socially and culturally situated, there are only locally situated citizens, persons in historical and geopolitical contexts and circumstances. From this perspective, the 'global citizen' is a neoliberal, Western construct; an expression of the attempt to enforce neo-imperial ideas aligned with colonialism and racism and associated forms of epistemic violence (see De Oliveira Andreotti, 2011, pp. 385, 386; Abdi et al., 2015, p. 3; Abdi, 2015, pp. 16, 18, 20, 21, 23; Swanson, 2015, pp. 28, 33).

Relationalism shares with localism an emphasis on identification with local culture and indigenous ways of knowing, but it also insists on openness towards other cultures, values and "knowledges". GCE has as its stated goal exposure to a diversity of epistemologies, all of which are equally valid and valuable. However, partiality remains part of the psychology of (global) citizens whose thinking and acts are, in the first instance, situated, relational and intersubjective. It is obvious that they are first and foremost concerned about those they are close to, within their family, circle of friends and acquaintances, and cultural sphere. This does not mean, however, that they do not (or should not) engage with, and are not (or should not be) concerned about strangers, foreigners, in short: the Other. Knowledge, like individual existence, is relational, communal (see Dei, 2014, p. 12; De Oliveira Andreotti, 2011, p. 391; Swanson, 2015): "I know because we know. Or, A knower is a knower because of other knowers". Knowledge in its various forms and manifestations is based on personal, social and cultural closeness and proximity.

Localism and relationalism are in agreement in their rejection of universal or global knowledge (Abdi et al., 2015, p. 5), epistemological hegemony and colonisation, and "mono-epistemicalisation" (Abdi, 2015, pp. 21, 23). Relationalism is understood to constitute an anti-colonial, "alternative globalisation movement" (Chan-Tiberghien, 2004, pp. 191, 208) that is incredulous of any overarching or colonising knowledge and truth. Both localism and relationalism invoke the notions of 'diverse epistemologies' and of "ecology of knowledges". 


\section{"Diverse epistemologies" and "ecology of knowledges"}

In their defence of what they call the "ecology of knowledges" Boaventura de Sousa Santos, João Arriscado Nunes and Maria Paula Meneses also speak of "the epistemological diversity of the world", which "is immense" (De Sousa Santos et al., 2008, pp. xix, xlviii). However, on the basis of the premise that "there is no global social justice without global cognitive justice" (De Sousa Santos et al., 2008, p. xix; see also Chan-Tiberghien, 2004, p. 196; De Oliveira Andreotti, 2011, p. 381), they relate this appeal not to different normative theories of knowledge, but rather to diversity across ethnicities and cultures, as well as to gender differences:

Over the last decades, there has been a growing recognition of the cultural diversity of the world, with current controversies focusing on the terms of such recognition. But the same cannot be said of the recognition of the epistemological diversity of the world, that is, of the diversity of knowledge systems underlying the practices of different social groups across the globe. (De Sousa Santos et al., 2008, p. xix)

Beginning with the assumption that "cultural diversity and epistemological diversity are reciprocally embedded", the authors' intention is to show that "the reinvention of social emancipation is premised upon replacing the 'monoculture of scientific knowledge' by an 'ecology of knowledges". In other words, "far from refusing science", the "alternative epistemology" envisaged here "places the latter in the context of diversity of knowledges existing in contemporary societies" (p. xx):

The ecology of knowledges is an invitation to the promotion of non-relativistic dialogues among knowledges, granting 'equality of opportunities' to the different kinds of knowledge engaged in ever broader epistemological disputes aimed both at maximizing their respective contributions to build a more democratic and just society, and at decolonizing knowledge and power. (De Sousa Santos et al., 2008, p. xx)

This exemplifies the recent but widespread (localist as well as relationalist) view that ethnic or cultural groups have their own distinctive epistemologies, that epistemologies are also gendered, and that these have been largely ignored by the dominant social group. A corollary of this view states that educational research is pursued within a framework that represents particular assumptions about knowledge and knowledge production that reflect the interests and historical traditions of this dominant group. Thus, many theorists emphasise decolonisation of knowledge, recognition of indigenous, local or subaltern knowledge systems and "radically different" epistemologies within a reconceptualised GCE (see Odora Hoppers, 2002a, p. vii; Odora Hoppers, 2002b, p. 18; Chan-Tiberghien, 2004, p. 205; 
De Oliveira Andreotti, 2011, pp. 387, 394; Die, 2014, pp. 10, 16, 19; Abdi, 2015, p. 20; Swanson, 2015; Higgs, 2018). Other popular, related ideas are "local, cultural ways of knowing" (Dei 2014: 11) and "non-Western" or "alternative epistemologies" (De Oliveira Andreotti, 2011, p. 385; Chan-Tiberghien, 2004, p. 205).

More often than not, however, in such arguments for different, diverse, alternative, decolonised or demasculinised epistemologies some relevant philosophical issues remain unresolved, if not unaddressed altogether. What exactly do these claims about epistemological diversity mean? Do these ways of establishing knowledge stand up to critical interrogation? Moreover, how do they relate to traditional epistemological distinctions, e.g. between knowledge and belief and between descriptive and normative inquiry, and to epistemologically essential components like justification, evidence, warrant, and truth?

\section{'Epistemology' - normative and descriptive conceptions}

Jon Levisohn and Denis Phillips explain that, especially in the educational literature on postcolonial reforms, the language of epistemology has been employed in some kind of rhetorical inflation, thus obscuring rather than clarifying important issues and distinctions (Levisohn and Phillips, 2012, p. 40). Traditionally, 'epistemology' refers to 'theory/logic of knowledge' (episteme - knowledge; logos - word). Over the centuries, beginning with Socrates and Plato, epistemologists have reached a general agreement about a basic distinction between knowledge and belief. The present concern is not just whether or not a word ('epistemology') is being misused, but more importantly whether or not the issues dealt with in epistemology (a complex field that has evolved over a long period of time) are being given short shrift, if not ignored altogether. A related distinction has been made between descriptive and normative inquiry, regarding beliefs and knowledge. "If these distinctions are blurred", the authors write, "then all rational argument is potentially undermined" (42), including the very arguments localists, relationalists and other postcolonial theorists employ. In order to establish some kind of conceptual clarity, Levisohn and Phillips draw the following distinctions:

1. epistemology as a normative field of inquiry,

2. an epistemology as a normative theory of knowledge,

3. an epistemology as a descriptive account of how people acquire beliefs,

4. an epistemology as a description of a set of beliefs.

The first of these refers to the classical philosophical understanding of knowledge. According to Socrates, in Plato's Meno (1970, p. 65),

True opinions, as long as they stay, are splendid and do all the good in the world, but they will not stay long - off and away they run out of the soul of mankind, so they are not worth much until you fasten them up with the reasoning of cause and effect.... When they are fastened up, first they become 
knowledge, secondly they remain; and that is why knowledge is valued more than right opinion, and differs from right opinion by this bond.

And in Plato's Theaetetus (1978, p. 909) the (rhetorical) question is, “... how can there ever be knowledge without an account and right belief?" Relevant distinctions are made here between knowledge and belief, between mere belief and well-warranted (or adequately justified) belief, and between true belief and justified true belief. The inquiry here is essentially normative, for example, evaluating beliefs and belief strategies, investigating which beliefs are trustworthy enough to be acted on, how researchers should validate their findings, what forms of argument and what kinds of justification are acceptable, who (if anyone) counts as an epistemic authority, etc. This is, incidentally, not an essentially or exclusively 'Western' philosophical understanding of knowledge. It should be noted, for example, that in Yoruba, too, pertinent distinctions are made between gbàgbó (belief; the subjective, private or personal component of knowledge) and mò (knowledge in the sense of 'knowledge-that'). Barry Hallen and J.O. Sodipo (1997, p. 81) observe that gbàgbó that may be verified is gbàgbó that may become mò. Gbàgbó that is not open to verification and must therefore be evaluated on the basis of justification alone (àlàyé, papò, etc.) cannot become mò and consequently its óótó [truth] must remain indeterminate.

The second point concerns different epistemologies within the philosophical tradition. Levisohn and Phillips distinguish between foundationalist (e.g., empiricist, rationalist, and positivist) and non-foundationalist (e.g., pragmatist) epistemologies. Here, too, the inquiry is normative. As the authors inform us, all these coexist because philosophers still disagree about them, even though they are in agreement that only one position can be right. This is not the case with appeals to 'multicultural epistemologies' - which (as their defenders contend) are all equally respectable and valid.

The third general use of 'epistemology' serves an essentially descriptive function and belongs less to philosophy than to the so-called 'sociology of knowledge' (which might be called, more fittingly, the 'sociology of belief') and perhaps to the psychology of learning. The fourth sense of 'epistemology' is also descriptive, in that it is sometimes extended to ... encompass description of the specific content of beliefs that are held, or are accorded the status of being knowledge, by ethnic or cultural groups ... In this ... usage, then, multicultural epistemologies are simply those differing sets of beliefs held by different communities. (Levisohn and Phillips, 2012, p. 54)

The authors point out, plausibly I think, that within the descriptive senses, the notion of multicultural epistemologies is unproblematic - given the interpretation of 'epistemologies' as 'beliefs' or 'belief systems'. There is, however, no coherent normative sense in which the existence of diverse epistemologies (multicultural or otherwise) can be affirmed. This is also Phillips's argumentational thread 
(Phillips 2012), where he provides a critical review of several representative accounts of 'multicultural epistemology' that actually constitute misuses of the term 'epistemology'.

\section{What are 'diverse epistemologies'?}

Harvey Siegel (2012) examines a number of senses in which 'epistemological diversity' is often used:

- diverse beliefs and belief systems,

- diverse (research) method(ologie)s,

- diverse research questions,

- diverse researchers and their cultures,

- diverse epistemologies and epistemological perspectives.

Although the use of 'epistemology' in the first four of these examples is arguably inappropriate (in that philosophers do not understand 'epistemology' in any of these ways), the use of 'diversity' is uncontroversial. Beliefs and belief systems vary, as do research questions and research methods (although this should not be taken as methodological relativism ${ }^{2}$ ). Similarly, there is a considerable variation in researchers' backgrounds, their individual, ethnic and cultural identities, their interests, objectives and priorities. The 'diversity' in question becomes more controversial, and indeed problematic, in relation to 'epistemologies and epistemological perspectives', insofar as there is a conflation of epistemological pluralism and epistemological relativism, and the plea for diverse epistemologies becomes an assertion of the coexistence of diverse 'truths' (see Higgs, 2018, p. 213; Swanson, 2015, p. 32; Abdi, 2015, p. 23). The debate about decolonisation and about ubuntu as an indigenous democratic model for citizenship education, for indigenising citizenship, illustrates these problems.

\section{Ubuntu as an ethnic model for decolonisation and indigenisation of citizenship}

Dalene Swanson (2015) proposes a key idea of African humanism, ubuntu, for the reconceptualization of GCE: "ubuntuizing global citizenship serves the purpose of decolonizing it" (34). Ubuntu represents a communal ontology and is the abbreviation of Umuntu ngumuntu ngabantu': 'A person is a person because of

2 Thus, Linda Tuhiwai Smith (1999: 183-195) refers to research in the context of Kaupapa Maoribased epistemology and methodology (see also Chan-Tiberghien, 2004, pp. 192, 197; Higgs, 2018, p. 213). The point is that compelling judgements can be made about the quality of competing research methodologies. Some are better than others, and some are plainly invalid.

3 Other equivalent ideas in southern Africa are botho (Motho ke motho ka batho) and hunhu (Munhu munhu navhanu). 
other persons', or: 'I am because we are'. According to Swanson, the philosophy of ubuntu, "with its emphasis on a social African humanism and spiritual way of collective being, provides the possibilities for replacing, reinventing and reimagining alternatives to the current destructive path of increasing global injustice, as it also offers opportunities to decolonize recuperative global citizenship discourses and coercive Western epistemologies" (33). Ubuntu embodies a philosophy "that community strength comes of community support, and that dignity and identity are achieved through mutualism, empathy, generosity $(, \ldots)$ community commitment... and moral and social harmony" (35). In 1996 Malegapuru Makgoba published a plea for ubuntu as a democratic ideal for South Africa (Makgoba, 1996; see also Enslin and Horsthemke, 2004). In contrast to Makgoba, Swanson does not appear to subscribe to a relativist conception of democracy and CE but emphasises, rather, a reconceptualisation of global citizenship that is based not only on decolonialisation but also on indigenisation (p. 33) - and on Africa's 'unique' contribution in this regard:

While other forms of indigenous thought and philosophy resonate with Ubuntu or might also offer important contributions to decolonizing global citizenship and its allied discourses, Ubuntu's distinctiveness in focussing on an ethics of collective care away from more individualistic interpretations is what gives it an important place in the decolonizing project. (p. 34)

For Swanson, like for Makgoba, ubuntu also has an epistemological dimension. Ubuntu, as an 'African way of knowing', is enacted and conceptualized as circular, organic and collectivist, rather than linear, unitized, materialistic and individualistic, as is attributed to Western perspectives.... Within such a collectivist philosophy, the affective, relational and moral philosophical tenets are fore-fronted and, in the context of post-colonization, the source of much African epistemological self-consciousness ... (p. 35)

The extension of the concept of truth is especially noteworthy in this regard. Based on the understanding of truth employed during the (South African) Truth and Reconciliation Commission hearings, 'truth ' comprises not only forensic truth but also personal or narrative truth, social or dialogical truth, as well as healing or restorative truth. ${ }^{4}$ Truth, like $u b u n t u$ and knowledge, is communal, relational, and

4 It is certainly debatable whether the latter three (non-forensic) conceptions actually concern truth - as contrasted with personal opinion, consensus, and reconciliation, respectively. There is a reason why the TRC was not called 'Belief and Reconciliation Commission' or 'Consensus and Reconciliation Commission'. It was tasked, first and foremost, with establishing what actually took place/happened/occurred, independently of what people sincerely believed, agreed on and perhaps even found comfort in. 
refers to what it means to be a person or fellow citizen and "to be in relationship with an-Other" (p. 34).

Swanson's argument is not weakened substantially by the interjection that ubuntu is not distinctive. Conceptual kinship can be established between $u b u n t u$ and the ancient Egyptian idea of maat, which emphasises harmony, moral virtue or goodness, and the need to locate and understand oneself and one's choices and behaviour in the context of the larger whole. This view also finds expression among Native Americans, in the Lakota phrase Mitakuye oyasin or the Cree notion of wahkohtowin ('All is related'; 'We are all related'), both of which refer to the selfdefined relationally, the self in relation. Thus, it is only the uniqueness and distinctiveness of ubuntu that are questioned here, but not its status as an ethic for the decolonisation of global citizenship.

A more serious problem is constituted, however, by the patriarchal practices that have come to be associated with ubuntu in southern Africa: polygamy, amaqhikiza (a type of mentorship programme among older and younger girls "to ensure sexual abstinence" until the latter are "ready to take full control of their affairs", and ukuhlolwa kwezintombi, or 'virginity testing' in girls, which "seeks to achieve the goal of purity in the context of the spread of HIV/AIDS" (Ntuli, 2002, pp. 61, 62). What makes the latter two practices objectionable is not only that similar testing is not applicable (and consequently never done) with regard to boys, but also that women are implicitly held responsible for the spread of HIV/AIDS. Furthermore, regarding the compatibility of ubuntu and polygamy, Mogobe Ramose states (2002, p. 329), "That marriage should not of necessity be monogamous is one of the ancient practices of ubuntu philosophy". Given the reality of (especially South) African polygamy, this declaration is tantamount to an endorsement of ' $u b u n t u$ for men'. The kind of relationality that is envisaged here follows androcentric and patriarchal ideas and precepts, which makes it difficult to reconcile ubuntu with GCE. However, the link is admittedly somewhat arbitrary, not essential. Through explicit dissociation from these customs the ethic of ubuntu could be modified and rendered applicable to and within $(\mathrm{G}) \mathrm{CE}$.

The strongest argument against using ubuntu in the context of GCE is presumably that the associated relativist understanding of knowledge and truth raises problems that are even more substantial than the difficulties around basic logical coherence and consistency. If knowledge and truth did differ from person to person, from society to society, and from culture to culture ${ }^{5}$, then what would

5 "The burgeoning literature on educational globalization ... has largely focused on a 'restructuring imperative', at the expense of a radically different epistemology", according to Jennifer Chan-Tiberghien (2004, p. 192; emphasis added). Ali Abdi (2015, p. 21; emphasis added) adds, "perhaps there is something that stands for some truth but it must be polycentrically constructed and practiced so it does not leave the real, lived experience of some out, thus potentializing their epistemic exile and attendant oppressive outcomes". 
be the implications - educational, political and other? First, it would not only be presumptuous but also impossible to evaluate or judge the knowledge- and truth-claims of others. Of course, this is something that would be welcomed by many, if not most, constructivists and postcolonial theorists. However, this kind of relativism is symmetrical. If it can be employed by the historically disenfranchised against the judgements and interpretational sovereignty of the powerful then it can also be used to immunise those in power from criticism by the disempowered. Second, if relativism were true, then, in order to decide what is right or wrong, and true or false, it would be sufficient merely to canvas opinions prevalent within one's own society or cultural group. What values, responsibilities, obligations and rights (if any) should adolescents be taught? What ought they to be shielded or protected from? Is direct democracy a form of government worth striving for - or is representative democracy preferable? What about forms of government like oligarchy, single-party rule or autocracy? This all depends on the locale, the context of the questioner, and does not allow any translocal, transcontextual answers. Thirdly, and lastly, one could not really say whether any progress has been taking place in a society, in terms of advancement in knowledge or democratic values. Given relativism, no transhistorical comparisons would be permissible, let alone possible. For example, women's voting rights, gay and lesbian marriage rights, or the overcoming of apartheid in South Africa could not be considered to constitute a democratic advancement or success. Similar considerations pertain to the normative discourses regarding 'reform' and 'transformation' within (G)CE. Thus, Philip Higgs's declaration (2018, pp. 220-221) that "a 'relevant' and responsible (global) citizenship education agenda will reveal a readiness to transform not only local societies, but also other societies in the interchange and interaction of epistemic networks in a global context when it comes to citizenship education" is illusory in more than one way, especially against the background of "radically different" epistemologies. It posits the possibility of both intrasocial/intracultural transformation and intersocial/intercultural exchange and cooperation. However, if epistemological and ethical relativism were true (assuming that assertions to this effect would not present insurmountable consistency and coherence problems for the advocacy of ubuntu), then Higgs's normative, diachronic agenda would be unmasked as a pipe dream.

\section{Epistemic injustice}

Does the account of knowledge and epistemology I endorse here not amount to a denial of epistemic justice? Take, as a further possible example, Siegel's no-holds-barred response to Claudia Ruitenberg's question regarding "indigenous African women's epistemologies”: “They're not epistemologies. If students don't understand that by the end of their graduate education, they haven't been well educated" (Code 
et al., 2012, p. 138). Could this possibly constitute some kind of epistemic harm vis$\grave{a}$-vis indigenous African women?

Miranda Fricker considers "epistemic injustice" to be a distinct kind of injustice. She distinguishes between two kinds, "testimonial injustice" and "hermeneutical injustice", each of which consists, "most fundamentally, in a wrong done to someone specifically in their capacity as a knower" (Fricker, 2007, p. 1; see also p. 21). Central to her analysis is the notion of (social) 'power', which Fricker defines as "a socially situated capacity to control others' actions" (p. 4). Power works "to create or preserve a given social order", and is displayed in various forms of enablement, on the one hand, and disbelief, misinterpretation and silencing, on the other. It involves the conferral on certain individuals or groups, qua persons of that kind, "a credibility excess" or "a credibility deficit" (p. 21). Fricker's interest resides specifically with "identity power" and the harms it produces through the manifestation of "identity prejudices". The latter are responsible for denying credibility to, or withholding it from, certain persons on the basis of their being members of a certain "social type" (ibid.). Thus, testimonial injustice involves rejecting the credibility of their knowledge claims, while hermeneutical injustice involves a general failure of marshalling the conceptual resources necessary for understanding and interpreting these knowledge claims. The result is that these people are hindered in their self-development and in their attainment of full human worth: they are "prevented from becoming who they are" (p. 5). In white patriarchal societies, these "epistemic humiliations" (p. 51) carry the power to destroy a would-be (black or female) knower's confidence to engage in the trustful conversations (pp. 52-53) that characterise well-functioning epistemic communities. As Fricker suggests, they can "inhibit the very formation of self" (p. 55). Although they are experienced (and may be performed) individually, testimonial and hermeneutical injustice constitute not only individual harms: they originate within a social fabric of which the biases and prejudices that enliven and perpetuate them are a characteristic part. Contesting such injustices and harms, according to Fricker, requires "collective social political change" (p. 8).

Considering how prejudice affects various levels of credibility, and also considering that scepticism about 'diverse epistemologies' has sometimes been part of a hegemonic discourse and constituted epistemic injustice, the question might now be raised whether my critique of this notion (and its affiliates, like 'indigenous knowledge' or 'local ways of knowing') is not part of this discourse. Louise Antony suggests the adoption of "epistemic affirmative action" by men as a "working hypothesis that when a woman, or any member of a stereotyped group, says something anomalous, they should assume that it's they who do not understand, not that it is the woman that is nuts" (Antony, 1995, p. 89; quoted in Fricker, 2007, p. 171). By contrast, Fricker does not believe a policy of epistemic affirmative action across all subject matters to be justified: "the best way to honour the compensatory idea is in the form of a capacity for indefinitely context-sensitive judgement - in the form... of a virtue" (Fricker, 2007, p. 171). At what point, then, 
can a white man judge a woman, or any member of a stereotyped group, to be 'nuts' - if ever? Does epistemic justice require me, as a matter of course, to reserve judgement, to keep "an open mind as to credibility" (p. 172)? If 'credibility deficit' is a matter of epistemic injustice, then why should 'credibility excess' (giving previously "epistemologically humiliated" people or groups excessive credibility) not also constitute epistemic harm? More fundamentally, and this point pertains to Siegel's response to Ruitenberg (concerning “indigenous African women's epistemologies"), surely there is a difference between criticising someone's view on the mere grounds that she is black, or a woman, and criticising the views held or expressed by someone, who happens to be black or a woman, on the grounds of faulty or fallacious reasoning. Nonsense is not culturally, racially or sexually specific. Indeed, although Fricker gestures in the direction of a basic 'do no harm' principle (p. 85), she also insists that a "vulgar' relativist" resistance to passing moral judgment on other cultures "is incoherent" (p. 106).

\section{The value of diversity within citizenship}

More recently, Emily Robertson (2013, p. 300) has argued that diversity is both an epistemic and a moral virtue, but that this argument "does not support alternative epistemologies, cognitive relativism, or the replacement of truth as an epistemic goal by, for example, beliefs that have progressive consequences". The value of diversity for knowledge resides in the possibility of different groups having "different experiences that lead them to know or believe things that escape others' attention": reports of their experiences may function as data that allows researchers to examine the social system or structure from their social location (p. 304).

While postcolonial theory arguably errs in postulating the existence of diverse knowledges and truths, the diversity in question is conceivably generated by (characteristically) practical epistemic priorities - priorities that emanate from different lived experiences, individual as well as social and cultural. A plausible view appears to be that knowledge and truth do not fluctuate, that they remain invariant across individuals, societies and cultures, but that there may well be distinctive sets of epistemic concerns that arise from particular personal, historical and socio-political circumstances. If it is correct to assume that practical epistemic and educational priorities will emerge from life experiences and from the ways these are socially articulated, then one might assume that, given the different life experiences of people across the globe, the practical epistemic and educational priorities will also differ.

For example, as Elizabeth Anderson has put it:

No one disputes that personal knowledge of what it is like to be pregnant, undergo childbirth, suffer menstrual cramps, and have other experiences of a female body is specific to women. Gynaecology has certainly progressed 
since women entered the field and have brought their personal knowledge to bear on misogynist medical practices. The claims get more controversial the more global they are in scope. Some people claim that women have gender-typical 'ways of knowing', styles of thinking, methodologies, and ontologies that globally govern or characterize their cognitive activities across all subject matters. For instance, various feminist epistemologists have claimed that women think more intuitively and contextually, concern themselves more with particulars than with abstractions, emotionally engage themselves more with individual subjects of study, and frame their thoughts in relational rather than an atomistic ontology... There is little persuasive evidence for such global claims. (2002, p. 325)

Interestingly, too, Anderson "does not suppose that women theorists bring some shared feminine difference to all subjects of knowledge" (p. 326).

Given, to use a further example, the experience of 'indigenous' Africans of a wide-ranging credibility deficit, it stands to reason that they would have as priorities matters of epistemic transformation and redress. If epistemic and educational concerns and priorities arise from different forms of social life, then those that have emerged from a social system in which a particular race or group has been subordinate to another deserve special scrutiny. Given the (especially vicious) history of physical and psychological colonisation, it is plausible that one of the epistemic and educational priorities will be to educate against development of a subordinate or inferior mindset, as well as against victim and beggar mentality, despite the continuing economic crisis and low level of economic growth. An additional priority arises with Africa's low literacy quotients. In many countries, the language of conceptualisation and education is the official language of administration: English, French or Portuguese, in which the majority of children and learners are not primarily competent. Consequently, there exist few successes in learning; quality and efficiency suffer; and high repeat and dropout rates mean a squandering of available resources. While it does not follow that particular historical and socio-economic circumstances yield or bestow automatic validation or justification of (the content and objectives of) an 'African epistemology', an idea like "decolonisation of the African mind" has a particular resonance here. Rather than implying a 'post-truth' epistemology, it involves 'going back to one's language' in 'thinking about thinking', examining one's 'own ways of conceptualisation'.

If what has been established above is cogent, it follows that so-called 'diverse epistemologies' refer neither to a multitude of truths nor to an 'anything goes' conception of justification, but rather to different experiences connected to particular social locations, or - as Robertson puts it - to different social pathways to knowledge (note the singular!). In this sense, reference to 'epistemologies' - like reference to "plural systems of knowledges" (De Sousa Santos et al., 2008, p. xxxix) 
or to indigenous, local or subaltern ways of knowing - is not only unhelpful but also misleading.

The promise of a modified cosmopolitanism for the real world, then, has in part to do with locality and context-specific relations - but not in terms of any exclusionist, 'hands-off' approach. Rather, it appears to be plausible that the particular historical, geographic and socio-cultural experiences of people give rise to particular priorities that shape their epistemic theory and practice - and also yield conceptual and epistemological tools that are likely to enrich (global) citizenship education and GCE research as a whole.

\section{Acknowledgements}

This paper was presented initially at a conference in Oulu, Finland, in June 2019. I wish to thank Katariina Holma, Anniina Leiviskä, Hanna-Maija Huhtala and Krassimir Stojanov for their generative feedback.

\section{References}

Abdi, A.A. (2015) Decolonizing Global Citizenship Education. In A. A. Abdi, L. Shultz \& T. Pillay (Eds.), Decolonizing Global Citizenship Education. Rotterdam, Boston \& Taipei: Sense.

Abdi, A.A., Shultz, L., \& Pillay, T. (2015). Decolonizing Global Citizenship. In: A.A. Abdi, L. Shultz \& T. Pillay (Eds.), Decolonizing Global Citizenship Education. Rotterdam, Boston \& Taipei: Sense.

Anderson, E. (2002). Feminist Epistemology: An Interpretation and a Defense. In K. B. Wray (Ed.), Knowledge \& inquiry: Readings in epistemology. Ontario \& New York: Broadview Press.

Antony, L. (1995). Sisters, Please, I'd Rather Do It Myself: A Defense of Individualism in Feminist Epistemology. Philosophical Topics, 23(2), 59-94.

Chan-Tiberghien, J. (2004). Towards a 'Global Educational Justice' Research Paradigm: Cognitive Justice, Decolonizing Methodologies and Critical Pedagogy. Globalisation, Societies and Education, 2(2), 191-213.

Code, L., Phillips, D.C., Ruitenberg, C.W., Siegel, H., \& Stone, L. (2012). Epistemological Diversity: A Roundtable. In C.W. Ruitenberg \& D.C. Phillips (Eds.), Education, Culture and Epistemological Diversity: Mapping a Contested Terrain. Dordrecht: Springer.

Dei, G.J.S. (2014). Global Education From an 'Indigenist' Anti-colonial Perspective. Journal of Contemporary Issues in Education, 9 (2), 4-23.

De Oliveira Andreotti, V. (2011). (Towards) Decoloniality and Diversality in Global Citizenship Education, Globalisation. Societies and Education, 9(3-4), 381-397.

De Sousa Santos, B., Nunes, J.A., \& Meneses, M.P. (2008). Introduction: Opening Up the Canon of Knowledge and Recognition of Difference. In B. De Sousa 
Santos (Ed.), Another Knowledge Is Possible: Beyond Northern Epistemologies. London \& New York: Verso.

Enslin, P. \& Horsthemke K. (2004). Can 'Ubuntu' Provide a Model for Citizenship Education in Democracy in African Democracies?. Comparative Education, 40(4), 545-558.

Fricker, M. (2007). Epistemic Injustice: Power and the Ethics of Knowing. Oxford: Oxford University Press.

Hallen, B., \& Sodipo, J.O. (1997). Knowledge, Belief, and Witchcraft: Analytical Experiments in African Philosophy. Stanford: Stanford University Press.

Higgs, P. (2018). Indigeneity and Global Citizenship Education: A Critical Epistemological Reflection. In I. Davies, L.-C. Ho, D. Kiwan, C.L. Peck, A. Peterson, E. Sant \& Y. Waghid (Eds.). The Palgrave Handbook of Global Citizenship and Education. London: Palgrave Macmillan.

Levisohn, J.A., \& Phillips, D.C. (2012). Charting the Reefs: A Map of Multicultural Epistemology. In C.W. Ruitenberg \& D. C. Phillips (Eds.), Education, Culture and Epistemological Diversity: Mapping a Contested Terrain. Dordrecht: Springer.

Makgoba, M.W. (1996). In Search of the Ideal Democratic Model for SA. Sunday Times (South Africa), October 27, p. 23.

Ntuli, P.P. (2002). Indigenous Knowledge Systems and the African Renaissance: Laying a Foundation for the Creation of Counter-hegemonic Discourses. In: C. A. Odora Hoppers (Ed.), Indigenous Knowledge and the Integration of Knowledge Systems: Towards a Philosophy of Articulation. Claremont: New Africa Books.

Nussbaum, M.C. (2002). Education for Citizenship in an Era of Global Connection. Studies in Philosophy and Education, 21(2), 289-303.

Odora Hoppers, C.A. (2002a). Introduction. In C.A. Odora Hoppers (Ed.), Indigenous Knowledge and the Integration of Knowledge Systems: Towards a Philosophy of Articulation. Claremont: New Africa Books.

Odora Hoppers, C.A. (2002b). Indigenous Knowledge and the Integration of Knowledge Systems: Towards a Conceptual and Methodological Framework. In C.A. Odora Hoppers (Ed.), Indigenous Knowledge and the Integration of Knowledge Systems: Towards a Philosophy of Articulation. Claremont: New Africa Books.

Pallas, A.M. (2001). Preparing Education Doctoral Students for Epistemological Diversity. Educational Researcher, 30(5), 6-11.

Papastephanou, M. (2005). Globalisation, Globalism and Cosmopolitanism as an Educational Ideal. Educational Philosophy and Theory, 37(3), 533-551.

Phillips, D.C. (2012). A Critical Review of Representative Sources On Multicultural Epistemology. In C.W. Ruitenberg, \& D.C. Phillips (Eds.), Education, Culture and Epistemological Diversity: Mapping a Contested Terrain. Dordrecht: Springer. Plato (1970). Meno, transl. by W.H.D. Rouse. In E.H. Warmington \& P.G. Rouse (Eds.), The Complete Texts of the Great Dialogues of Plato. New York, Toronto \& London: Plume. 
Plato (1978). Theaetetus. In E. Hamilton \& H. Cairns (Eds.), Plato - Collected Dialogues. Princeton: Princeton University Press.

Ramose, M.B. (2002). The Ethics of Ubuntu. In P. H. Coetzee \& A.P.J. Roux (Eds.), Philosophy from Africa. Cape Town: Oxford University Press Southern Africa.

Robertson, E. (2013). The Epistemic Value of Diversity. Journal of Philosophy of Education, 47(2), 299-310.

Siegel, H. (2012). Epistemological Diversity and Education Research: Much Ado About Nothing Much? In C.W. Ruitenberg \& D.C. Phillips (Eds.), Education, Culture and Epistemological Diversity: Mapping a Contested Terrain. Dordrecht: Springer.

Smith, L.T. (1999). Decolonizing Methodologies: Research and Indigenous Peoples. New York: Zed Books.

Swanson, D.M. (2015). Ubuntu, Indigeneity, and an Ethic for Decolonizing Global Citizenship. In A.A. Abdi, L. Shultz \& T. Pillay (Eds.), Decolonizing Global Citizenship Education. Rotterdam, Boston \& Taipei: Sense.

\section{EDUKACJA DO OBYWATELSKOŚCI GLOBALNEJ A IDEA EPISTEMOLOGII ZRÓŻNICOWANYCH}

Streszczenie: Odnośnie edukacji do obywatelskości (globalnej) da się wyróżnić co najmniej trzy orientacje: kosmopolityzm, lokalizm i relacjonalizm. Od różniają się one odmiennym podejściem do przekazywania nie tylko kultury, lecz równie wiedzy i jej tworzenia. Autor stawia sobie za cel zbadanie pojęcia lokalnej (rdzennej) wiedzy w badaniach na temat edukacji do obywatelskości (globalnej) i rozstrzygnięcie na tej podstawie kwestii: Czy postkolonialna idea zróżnicowania epistemologicznego nie zawiera błędnego pojęcia epistemologii? Jego zdaniem istnieją racje uzasadniające konieczność jednoznacznego i uniwersalnego rozumienia wiedzy i epistemologii - w tym również w zakresie edukacji do obywatelskości (globalnej) i badaniach na ten temat. Przyjęcie tych racji umożliwia rozróżnienie między wiedzą a niewiedzą. W przeciwieństwie do tego miejsce zamieszkania, przynależność etniczna, rasowa ani płeć nie dostarczają wystarczających kryteriów do przeprowadzenia takiego rozgraniczenia. Opracowania, w których autorzy powołują się na dane te jako kryteria epistemologiczne, powinny być rozważane nie jako wypowiedzi o charakterze epistemologicznym, lecz pytania o sprawiedliwość społeczną.

Słowa kluczowe: edukacja; obywatelskość; epistemologia; różnorodność. 